\title{
ANALISIS BIAYA OPERASIONAL KENDARAAN (BOK) DAN WTP (WILLINGNESS TO PAY) PADA BUS AKAP JURUSAN BANJARMASIN - SAMARINDA
}

\author{
${ }^{1)}$ Bagus Nugroho Putra \\ ${ }^{2)}$ Utami Sylvia Lestari \\ ${ }^{1)}$ Teknik Sipil Universitas Lambung Mangkurat Banjarbaru \\ E-mail: bagusnugrohoputra@yahoo.co.id \\ ${ }^{2)}$ Teknik Sipil Universitas Lambung Mangkurat Banjarbaru \\ E-mail: utami.s.lestari@ulm.ac.id
}

\begin{abstract}
ABSTRAK
Kota Banjarmasin adalah ibu kota provinsi dari Kalimantan Selatan dengan berbagai macam aktivitas. Salah satu angkutan umum Kota Banjarmasin adalah bus AKAP (Antar Kota Antar Provinsi) PO. Pulau Indah Jaya yang melayani transportasi penumpang dengan tujuan kota dan provinsi. Sarana transportasi memiliki tarif biaya yang ditentukan berdasarkan Biaya Operasional Kendaraan (BOK). Tujuan penelitian ini untuk mengetahui besar BOK bus AKAP dengan metode Pacific Consultant International (PCI) dan untuk mengetahui besar tarif yang diinginkan penumpang beserta tanggapan terhadap tarif yang berlaku saat ini Willingness To Pay (WTP). Penelitian ini dilakukan melalui survei wawancara untuk BOK kepada pihak PO. dan sopir bus dengan jumlah data 25 unit bus dan untuk WTP survei wawancara dengan sampel 200 penumpang bus di terminal KM 6 tempat pembelian tiket bus. Besar BOK yang dikeluarkan oleh PO. Pulau Indah Jaya $\mathrm{Rp} \operatorname{Rp}$ 8.137.912.279 /tahun (bus Non AC) dengan tarif Rp 168.194 /penumpang dan Rp 8.712.239.580/tahun (bus AC+Toilet) dengan tarif Rp 229.173 /penumpang. Besar nilai WTP bus Non AC Rp 185.000 /penumpang dan AC+Toilet Rp 245.000 /penumpang. Tanggapan terhadap tarif bus AKAP Non AC Rp 175.000 /penumpang dan AC+Toilet Rp 235.000 /penumpang adalah harga tarif bus sesuai dengan kemampuan penumpang membayar dan mau membayar lebih dengan syarat adanya penambahan pelayanan dan fasilitas.
\end{abstract}

Kata Kunci: Bus AKAP, Biaya Operasional Kendaraan (BOK), Willingness To Pay (WTP)

\begin{abstract}
Banjarmasin city is the capital of the province of South Borneo with a wide range of activities. One of the public transportation of Banjarmasin city is the bus AKAP (Inter-City Inter Province) PO. Pulau Indah Jaya which serves passenger transportation with a city and provincial destinations. Transportation facilities have a fee that is determined based on Vehicle Operating Costs (VOC). The purpose of this study is to find out the size of the bus AKAP VOC with the Pacific Consultant International (PCI) method and to find out the number of tariffs desired by passengers along with responses to the current rates of Willingness To Pay (WTP). This research was conducted through interview surveys for VOC to PO. parties and bus drivers with data on 25 bus units and for WTP interview
\end{abstract}


surveys with a sample of 200 bus passengers at the terminal KM 6 places to buy bus tickets. VOC amount issued by PO. Pulau Indah Jaya Rp. 8.137.912.279 /year (Non AC buses) with a tariff of Rp 168.194 /passenger and Rp. 8.712.239.580 year (AC + Toilet bus) at a rate of $R p .229 .173$ /passenger. The value of the Non AC WTP bus is Rp. 185.000 /passenger and the AC + Toilet Rp. 245.000 /passenger. The response to the AKAP Non AC bus fare of Rp. 175.000 /passenger and AC + Toilet Rp. 235.000 /passenger is the price of the bus fare according to the ability of the passengers to pay and pay more on the condition of additional services and facilities.

Keywords: Bus AKAP, Vehicle Operating Costs (VOC), willingness to pay (WTP)

\section{PENDAHULUAN}

Kota Banjarmasin adalah ibu kota provinsi dari Kalimantan Selatan. Suatu pusat wilayah perkotaan dengan berbagai macam aktivitas mulai dari pendidikan, perdagangan, perkantoran, wisata kuliner dan pariwisata. Salah satu angkutan umum yang akan di bahas yaitu bus AKAP (Antar Kota Antar Provinsi) sebagai alat transportasi bus AKAP ini dapat membantu masyarakat yang tidak memiliki kendaraan pribadi atau enggan menggunakan kendaraan pribadi mereka untuk perjalanan jauh seperti antar provinsi. Setiap sarana transportasi memiliki tarif biaya yang tertera pada jasa angkutan umum tersebut. Tarif biaya sebuah angkutan umum ditentukan berdasarkan (BOK) Biaya Operasional Kendaraan yang telah diperhitungkan oleh penyedia jasa angkutan. Faktor kenaikan harga BBM dan harga suku cadang dapat memberikan dampak terhadap kenaikan tarif. Alasan dari dilakukannya penelitian analisis BOK dan WTP adalah untuk mengetahui biaya yang harus dikeluarkan dalam Biaya Operasional Kendaraan (BOK) bus AKAP dan menilai apakah tarif yang telah ditetapkan memberikan keuntungan bagi pengguna jasa angkutan umum bus serta bagi pegawai dan perusahaan serta mengetahui presepsi atau tanggapan atas kemauan penumpang dalam membayar tarif bus, serta apakah tarif bus sudah sesuai dengan kemauan penumpang atau sebaliknya. Penelitian ini dilakukan pada angkutan umum bus AKAP PO. Pulau Indah Jaya dengan jalur tujuan Banjarmasin-Samarinda.

\section{TINJAUAN PUSTAKA}

Berdasarkan pertimbangan mutu dan umur kendaraan, kendaraan tua tidak mampu ditingkatkan lagi, karena besarnya biaya operasi dan pemeliharaan. Maka sebaiknya kendaraan tua diganti dengan kendaraan yang baru dengan kondisi yang baik (Ruslan, 2004).

\section{Biaya Tetap (Fixed Cost)}

Biaya tetap merupakan biaya yang akan terus dikeluarkan mulai dari awal dioperasikannya angkutan kendaraan hingga tidak beroperasi lagi. Biaya ini dalam pengeluarannya tidak tergantung seberapa sering dioperasikannya atau tidak. Pada umumnya biaya ini dikeluarkan per sekian bulan, 6 bulan dan tahun dengan besar biaya yang relatif sama. Beberapa komponen biaya tetap adalah:

1) Biaya Penyusutan Kendaraan

2) Biaya Modal Kendaraan 
3) Biaya Perijinan

4) Biaya KIR

5) Biaya STNK

6) Biaya Asuransi

7) Biaya Gaji Supir Dan Kernet

\section{Biaya Tidak Tetap (Variable Cost)}

Biaya tidak tetap ialah besarnya biaya kendaraan saat beroperasi dan perawatan yang dipengaruhi oleh jarak tempuh, banyak sedikitnya penumpang, dan besarnya kerusakan pada kendaraan. Beberapa komponen biaya tidak tetap adalah 1) Pemakaian Bahan Bakar Minyak (BBM), 2) Biaya penggunaan Ban, 3) Pemakaian Oli Pelumas, 4) Biaya Perawatan Kendaraan dan 5) Retribusi Terminal.

\section{Biaya Overhead}

Biaya overhead merupakan biaya tambahan yang berasal dari $10 \%$ sampai $15 \%$ dari biaya tetap dan tidak tetap. Biaya ini digunakan untuk membayar keperluan biaya operasi kendaraan dan biaya keperluan kantor lainnya. Besar persen biaya overhead ini didasarkan pada PerPres no. 54 pasal 66.

\section{Biaya Operasional Kendaraan (BOK) Metode PCI}

Biaya operasi kendaraan merupakan biaya kendaraan dari keseluruhan kegiatan yang dilakukan mulai dari pengisian bahan bakar, perawatan hingga pembayaran upah awak kendaraan. Penetapan nilai operasi kendaraan terdiri dari penetapan harga layanan transportasi dengan tujuan memaksimalkan kepentingan penyedia jasa tanpa melupakan kesejahteraan masyarakat. LRMC (Long Run Marginal Cost) adalah kondisi stabil jangka panjang yang mempengaruhi penetapan harga dengan memperhatikan kelangsungan harga dimasa depan (Button, 1993). Berikut ini rumus perhitungan BOK metode PCI untuk bus besar (Nuryati, Sri., 2012) sebagai berikut :

A. Konsumsi Bahan Bakar Minyak

$\mathrm{Y}=0,12922 \mathrm{~S} * \mathrm{~S}-13,68742 \mathrm{~S}+541,0279$

Dimana: $\quad \mathrm{Y}=$ Konsumsi bahan bakar (Liter/1000 km)

$\mathrm{S}=$ Running speed $(\mathrm{km} / \mathrm{jam})$

B. Konsumsi Oli

$\mathrm{Y}=0,00030 \mathrm{~S} * \mathrm{~S}-0,12968 \mathrm{~S}+7,062390$

Dimana : $\quad \mathrm{Y}=$ Konsumsi oli (Liter/1000 km)

$\mathrm{S}=$ Running speed $(\mathrm{km} / \mathrm{jam})$

C. Konsumsi Ban

$\mathrm{Y}=0,0012356 \mathrm{~S}-0,0064667$

Dimana: $\quad \mathrm{Y}=$ Konsumsi ban $(/ 1000 \mathrm{~km})$

$\mathrm{S}=$ Running Speed $(\mathrm{km} / \mathrm{jam})$

$\mathrm{Y}^{\prime}=\mathrm{Y}^{*}$ jumlah ban $*$ harga ban $(/ 1000 \mathrm{~km})$

D. Biaya Pemeliharaan dan Perbaikan

a) Biaya Suku Cadang

$\mathrm{Y}=0,0000320 \mathrm{~S}+0,0020891$ 
Dimana: $\quad \mathrm{Y}=$ Biaya suku cadang $(/ 1000 \mathrm{~km})$

$\mathrm{S}=$ Running speed $(\mathrm{km} / \mathrm{jam})$

$\mathrm{Y}^{\prime}=\mathrm{Y}^{*}$ nilai kendaraan $(/ 1000 \mathrm{~km})$

b) Biaya Pemeliharaan

$\mathrm{Y}=0,02311 \mathrm{~S}+1,97733$

Dimana : $\quad \mathrm{Y}=$ Koefisin biaya pemeliharaan $(/ 1000 \mathrm{~km})$

$\mathrm{S}=$ Running speed $(\mathrm{km} / \mathrm{jam})$

$\mathrm{Y}^{\prime}=\mathrm{Y}^{*}$ ongkos mekanik $(/ 1000 \mathrm{~km})$

E. Biaya Penyusutan

$Y=\left(\frac{1}{8,756 \mathrm{~S}+350}\right)$

Dimana : $\quad \mathrm{Y}=$ Penyusutan kendaraan $(/ 1000 \mathrm{~km})$

$\mathrm{S}=$ Running speed $(\mathrm{km} / \mathrm{jam})$

F. Biaya Suku Bunga Modal

$\mathrm{Y}=\left(\frac{120}{2500 \times \mathrm{S}}\right)$

Dimana : $\quad \mathrm{Y}=$ Suku Bunga $(/ 1000 \mathrm{~km})$

$\mathrm{S}=$ Running speed $(\mathrm{km} / \mathrm{jam})$

G. Biaya Asuransi

$\mathrm{Y}=\left(\frac{40 \times 0,5}{2500 \times \mathrm{S}}\right)$

Dimana : $\quad \mathrm{Y}=$ Biaya asuransi $(/ 1000 \mathrm{~km})$

$\mathrm{S}=$ Running speed $(\mathrm{km} / \mathrm{jam})$

H. Biaya Awak Kendaraan

$\mathrm{Y}=\left(\frac{1000}{\mathrm{~s}}\right)$

Dimana: $\quad \mathrm{Y}=$ Waktu perjalanan $(/ 1000 \mathrm{~km})$

$\mathrm{S}=$ Running speed $(\mathrm{km} / \mathrm{jam})$

I. Biaya Overhead

$\mathrm{Y}=10 \%$ dari sub total biaya operasi kendaraan

\section{Willingness To Pay (WTP)}

Kemauan penumpang untuk membayar biaya transportasi yang telah digunakannya. Pendekatan pada analisa WTP berdasarkan tanggapan penumpang terhadap tarif biaya dan pelayanan jasa transportasi (Tamin dkk, 1999). Beberapa faktor yang mempengaruhi WTP:

a. Persepsi penumpang mengenai kualitas pelayanan

b. Utilitas atau kepuasan penumpang terhadap jasa transportasi

c. Fasilitas yang lengkap atau tidak lengkap

d. Besarnya penghasilan penumpang

Nilai WTP berasal dari pengelompokan persepsi penumpang yang sama jenis pekerjaannya terhadap tarif transportasi yang digunakan (Zulfikar, 2015): 
$\mathrm{WTP}_{\text {Jenis Pekerjaan }}=\frac{\left.\sum \text { (tarif yang dipilih } \mathrm{x} \text { jumlah responden }\right)}{\text { Jumlah responden tiap jenis pekerjaan }}$

$\mathrm{WTP}_{\text {Semua Kategori Pekerjaan }}=\frac{\sum\left(\mathrm{WTP}_{\text {Jenis Pekerjaan }}\right)}{\text { Jumlah kategori pekerjaan }}$

\section{Populasi dan Sampel}

Populasi merupakan sekumpulan orang atau objek yang memiliki kesama-an dalam satu atau beberapa hal dan yang membentuk masalah pokok dalam suatu riset khusus. Sedangkan sampel merupakan unsur-unsur yang di ambil dari populasi. Rumus menentukan jumlah sampel sebagai berikut Nazir (2003):

$$
\mathrm{n}=\frac{\mathrm{NP}(1-\mathrm{P})}{(\mathrm{N}-1) \mathrm{D}+\mathrm{P}(1-\mathrm{P})} \quad \mathrm{D}=\frac{\mathrm{B}^{2}}{4}
$$

Keterangan:

$\mathrm{n}=$ jumlah sampel yang dicari

$\mathrm{P}=$ proporsi populasi

$\mathrm{N}=$ jumlah populasi

$4=$ konstanta

$\mathrm{B}=$ Bond of error dalam pengambilan sampel

Menurut Isgianto (2009), nilai $\mathrm{P}$ berasal dari survei sebelumnya, tetapi bila nilai $\mathrm{P}$ tidak diketahui maka harus mencari sampel sebanyaknya. Nilai sampel terbesar dari $\mathrm{P}(1-\mathrm{P})$ yaitu saat $\mathrm{P}=0,5$ dengan arti nilai derajat ketepatan $95 \%$ atau Bouond of error $(\mathrm{B})=0,05$.

\section{METODE PENELITIAN}

\section{Pengumpulan Data}

Mengumpulkan data yang digunakan untuk analisis dan pembahasan. Jika sudah dikelompokkan maka data tersebut direkapitulasi dalam bentuk tabel sehingga saat data dipakai untuk perhitungan lebih enak dilihat dan mudah dikoreksi jika ada kesalahan.

\section{Data Primer}

Data primer ialah data yang berisi tentang: 1). data kendaraan angkutan umum bus AKAP jalur Banjarmasin-Samarinda seperti harga bus, kecepatan rata-rata bus dioperasikan. 2) data jenis suku cadang yang digunakan bus AKAP jalur Banjarmasin-Samarinda. 3) tanggapan penumpang tarif bus AKAP terhadap kemampuan dan kemauan penumpang membayar.

\section{Data Sekunder}

Data sekunder ialah data yang berisi tentang: 1). data admisnistasi bus AKAP jalur Banjarmasin-Samarinda seperti biaya STNK dan biaya KIR. 2) data harga suku cadang yang diperoleh data harga pembelian dari PO. Pulau Indah Jaya dan data harga pasar. 


\section{Pengambilan Sampel}

Menurut Nazir (2003), rumus cara menentukan jumlah sampel adalah berikut ini:

$$
\begin{array}{ll}
\begin{array}{ll}
\text { Jumlah bus } & =10 \text { unit/hari } \\
\text { Rata-rata penumpang } & =40 \text { orang } \\
\text { Populasi (N) } & =10 \text { unit bus } \times 40 \text { orang } \\
& =400
\end{array} \\
\begin{array}{rl}
\mathrm{n}=\frac{400 \times 0,5(1-0,5)}{(400-1) 0,000625+0,5(1-0,5)} & \mathrm{D}=\frac{0,05^{2}}{4} \\
\mathrm{n}=200,25 & \mathrm{D}=0,0625
\end{array}
\end{array}
$$

Jadi, jumlah sampel yang perlu dikumpulkan adalah 200 buah sampel.

\section{Analisis Data dan Pembahasan}

Tahap ini dilakukan setelah dikumpulkannya data dari hasil wawancara menggunakan kuesioner telah disusun dengan rapi. Berikut ini langkah awal yang akan dilakukan setelah data didapat:

1. Menganalisis data dapat digunakan atau tidak digunakan.

2. Data telah dinyatakan bisa digunakan, maka data tersebut bisa dilanjutkan ke tahap perhitungan. Pada perhitungan Biaya Operasional Kendaraan (BOK) menggunakan metode PCI dan perhitungan WTP (Willingness To Pay).

3. Pembahasan hasil dari perhitungan BOK akan disesuai dengan tujuan dan maksud dari penelitian ini dilakukan.

4. Pembahasan WTP hasil tanggapan penumpang akan disesuai dengan tujuan dan maksud dari penelitian ini dilakukan. 
Tahapan-tahapan penelitian dapat dilihat Gambar 1. Diagram Alir Penelitian (flow chart) sebagai berikut :

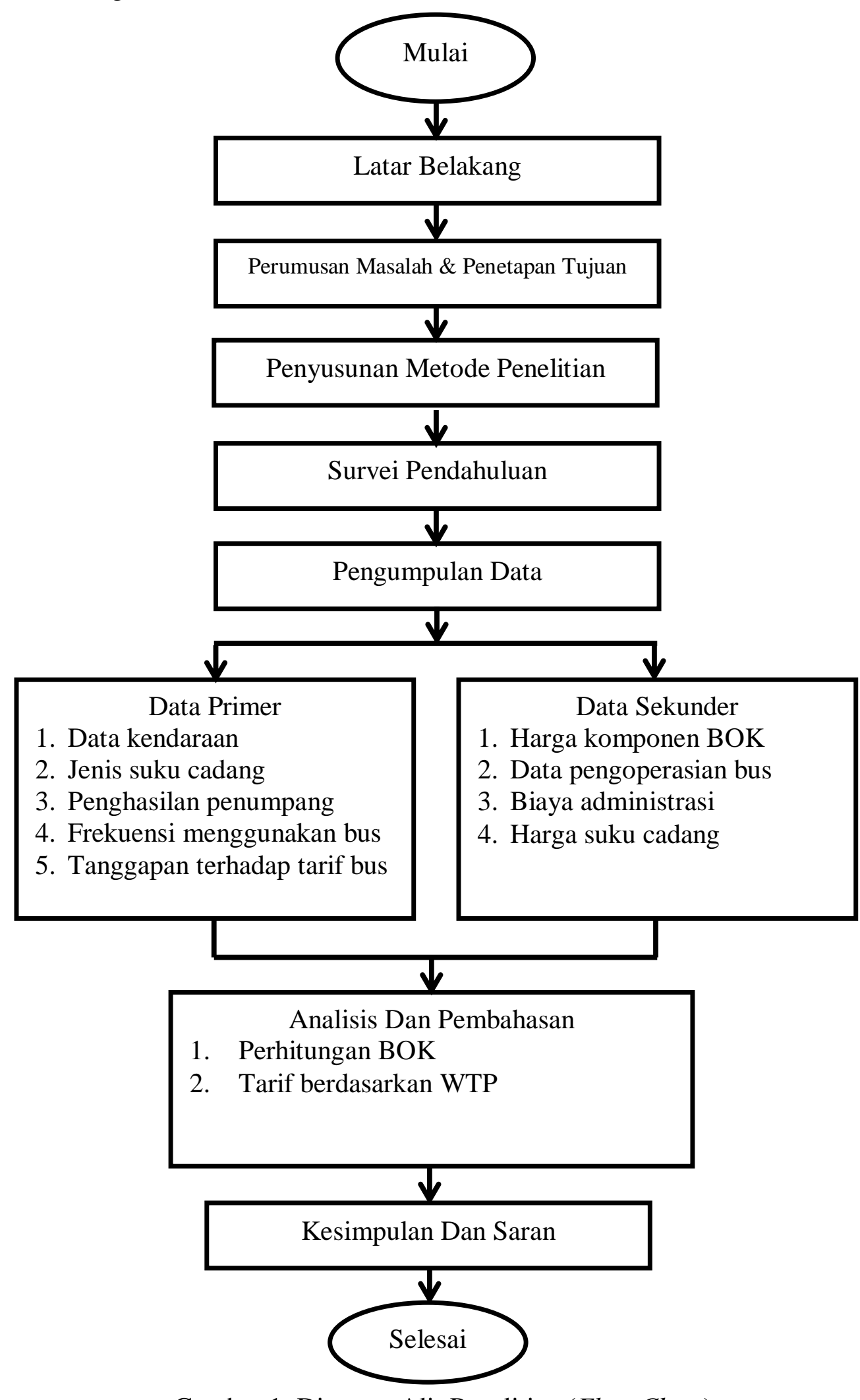

Gambar 1. Diagram Alir Penelitian (Flow Chart) 


\section{HASIL DAN PEMBAHASAN}

Sampel data Bus AKAP (Angkutan Antar Kota Antar Provinsi) :
1. Tarif tiket Non AC
2. Tarif tiket $\mathrm{AC}+$ Toilet
$=$ Rp. $175.000 /$ penumpang
3. Kapasitas angkut penumpang
$=$ Rp. $235.000 /$ penumpang
4. Kapasitas bahan bakar
$=43$ orang
5. Jenis bahan bakar
$=300$ liter
6. Jumlah ban
$=$ solar
$=6$ buah
7. Jarak tempuh
$=750 \mathrm{~km}$
8. Waktu tempuh Non AC
$=15 \mathrm{jam}$
9. Waktu tempuh AC + Toilet
$=15 \mathrm{jam} 30$ menit
10. Kecepatan rata-rata bus
$=70 \mathrm{~km} / \mathrm{jam}$
11. Running speed Non AC
$=750 \mathrm{~km} / 15 \mathrm{jam}=50 \mathrm{~km} / \mathrm{jam}$
12. Running speed $\mathrm{AC}+$ Toilet
$=750 \mathrm{~km} / 15,5 \mathrm{jam}=48,387 \mathrm{~km} / \mathrm{jam}$
13. Jumlah trip dalam 1 tahun
$=192 \mathrm{kali}$
14. Produksi layanan dalam 1 tahun
$=192 \times 750=144000 \mathrm{~km}$

\section{Biaya Operasional Kendaraan}

Hasil perhitungan BOK dapat dilihat pada Tabel.1 dan Tabel 2 sebagai berikut :

Tabel 1. Data Biaya Tidak Tetap dan Biaya Tetap Bus AKAP Non AC

\begin{tabular}{|r|r|r|r|}
\hline \multirow{2}{*}{ No } & No. Plat Kendaraan & Biaya Tidak Tetap & \multicolumn{1}{c|}{ Biaya Tetap } \\
\cline { 3 - 4 } & & $($ Rp/Tahun $)$ & (Rp/Tahun) \\
\hline 1 & KT 7299 AN & $223,733.736$ & 350.144 .000 \\
\hline 2 & KT 7382 AK & 238.133 .736 & 317.577 .000 \\
\hline 3 & DA 7828 AC & 225.094 .104 & 320.164 .000 \\
\hline 4 & KT 7261 AK & 226.582 .272 & 289.910 .000 \\
\hline 5 & KT 7025 AK & 228.226 .176 & 245.504 .000 \\
\hline 6 & DA 7828 AA & 238.133 .736 & 317.562 .000 \\
\hline 7 & KT 7755 AK & 225.819 .648 & 277.720 .000 \\
\hline 8 & KT 7230 AK & 225.094 .104 & 240.901 .000 \\
\hline 9 & KT 7828 AM & 239.121 .072 & 313.692 .800 \\
\hline 10 & KT 7269 AN & 224.362 .872 & 286.375 .000 \\
\hline 11 & KT 7039 AK & 226.582 .272 & 256.410 .000 \\
\hline 12 & KT 7319 AK & 223.733 .736 & 350.134 .000 \\
\hline 13 & KT 7028 AO & 224.721 .072 & 306.979 .000 \\
\hline 14 & KT 7158 AK & 238.133 .736 & 317.557 .000 \\
\hline & Total & 3.207 .472 .272 & 4.190 .629 .800 \\
\hline
\end{tabular}

Sumber: Perhitungan BOK Bus AKAP Non AC 
Overhead $=$ Rp. 739.810.207/tahun

BOK $=$ Rp. 8.137.912.279/tahun

Tarif $\quad=$ Rp. $168.194 /$ penumpang

Tabel 2. Data Biaya Tidak Tetap dan Biaya Tetap Bus AKAP AC+Toilet

\begin{tabular}{|c|c|c|c|}
\hline \multirow{2}{*}{ No } & \multirow{2}{*}{ No. Plat Kendaraan } & Biaya Tidak Tetap & Biaya Tetap \\
\hline & & (Rp/Tahun) & (Rp/Tahun) \\
\hline 1 & KT 7666 AK & 389.022 .400 & 307.296 .000 \\
\hline 2 & KT 7299 AK & 388.100 .800 & 304.126 .000 \\
\hline 3 & KT 7288 AN & 403.422 .400 & 263.104 .000 \\
\hline 4 & KT 7828 AW & 388.100 .800 & 351.999 .000 \\
\hline 5 & KT 7383 AK & 402.500 .800 & 339.004 .000 \\
\hline 6 & KT 7828 AQ & 389.022 .400 & 357.034 .000 \\
\hline 7 & KT 7828 AY & 389.310 .400 & 359.120 .000 \\
\hline 8 & KT 7209 AK & 388.100 .800 & 303.346 .000 \\
\hline 9 & KT 7368 AK & 402.500 .800 & 368.355 .000 \\
\hline 10 & KT 7268 AN & 403.249 .600 & 296.396 .000 \\
\hline 11 & KT 7918 AN & 403.249 .600 & 323.857 .000 \\
\hline & Total & 4.346 .580 .800 & 3.573 .637 .000 \\
\hline
\end{tabular}

Sumber: Perhitungan BOK Bus AKAP AC+Toilet

Overhead $=$ Rp. 792.021.780/tahun

BOK $=$ Rp. 8.712.239.580/tahun

Tarif $=$ Rp. $229.173 /$ penumpang

2. Analisis Berdasarkan WTP (Willingness To Pay)

Analisis WTP yang diperoleh dari penumpang jasa angkutan umum bus AKAP jalur Banjarmasin-Samarinda tentang penambahan tarif bus.

Tabel 3. Perhitungan Frekuensi Kumulatif WTP Bus Non AC

\begin{tabular}{|c|c|c|c|c|}
\hline No & Nilai WTP (Rp) & Frekuensi & Kumulatif & Persen \\
\hline 1 & 180.000 & 11 & 54 & $100.00 \%$ \\
\hline 2 & 185.000 & 4 & 43 & $79.63 \%$ \\
\hline 3 & 190.000 & 9 & 39 & $72.22 \%$ \\
\hline 4 & 195.000 & 9 & 30 & $55.56 \%$ \\
\hline 5 & 200.000 & 20 & 21 & $38.89 \%$ \\
\hline 6 & 205.000 & 1 & 1 & $1.85 \%$ \\
\hline & & 54 & & \\
\hline
\end{tabular}

Sumber: Perhitungan Frekuensi Kumulatif WTP Bus Non AC 


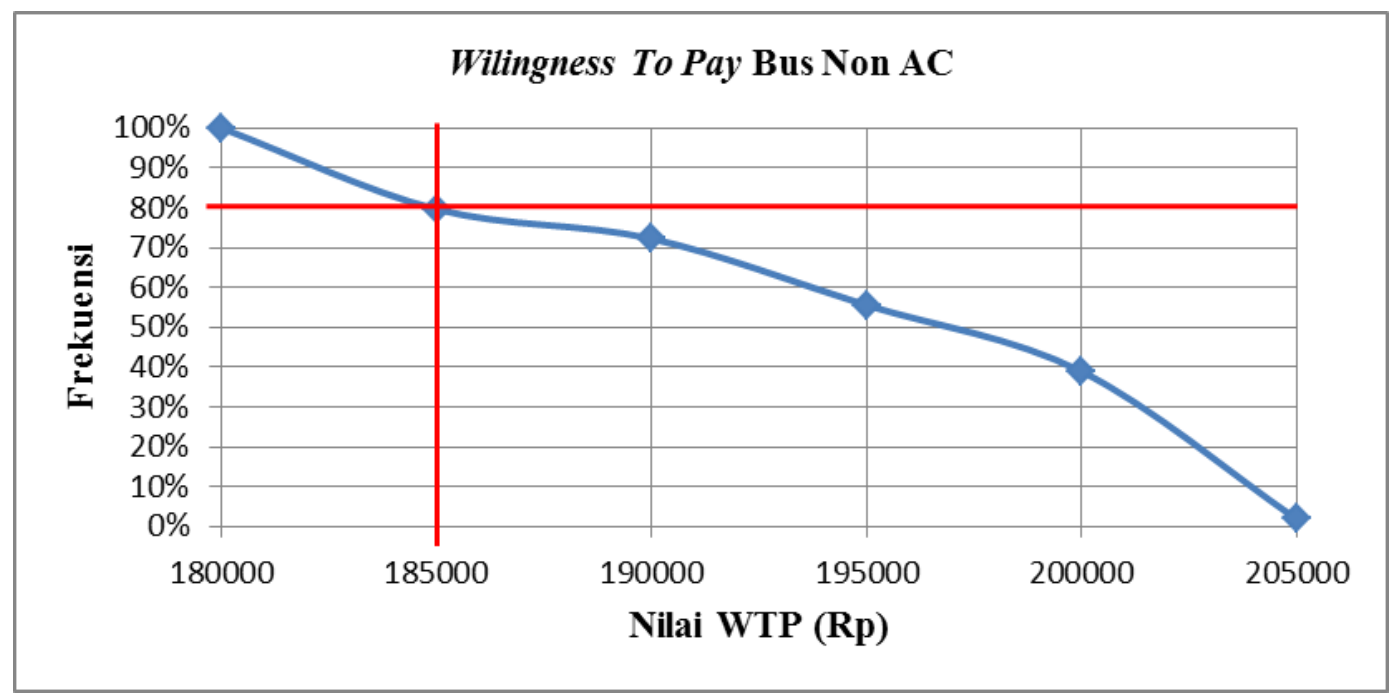

Gambar 2. Kurva Willingness To Pay Bus Non AC

Hasil kurva Willingness To Pay bus Non AC dipilih $80 \%$ frekuensi responden dengan nilai WTP sebesar Rp 185.000.

Tabel 4. Perhitungan Frekuensi Kumulatif WTP Bus AC+Toilet

\begin{tabular}{|c|c|c|c|c|}
\hline No & Nilai WTP (Rp) & Frekuensi & Kumulatif & Persen \\
\hline 1 & 240000 & 2 & 25 & $100 \%$ \\
\hline 2 & 245000 & 3 & 23 & $92 \%$ \\
\hline 3 & 250000 & 4 & 20 & $80 \%$ \\
\hline 4 & 255000 & 12 & 16 & $64 \%$ \\
\hline 5 & 260000 & 2 & 4 & $16 \%$ \\
\hline 6 & 265000 & 2 & 2 & $8 \%$ \\
\hline \multicolumn{2}{|r|}{ Total } & 25 & & \\
\hline
\end{tabular}

Sumber: Perhitungan Frekuensi Kumulatif WTP Bus AC+Toilet

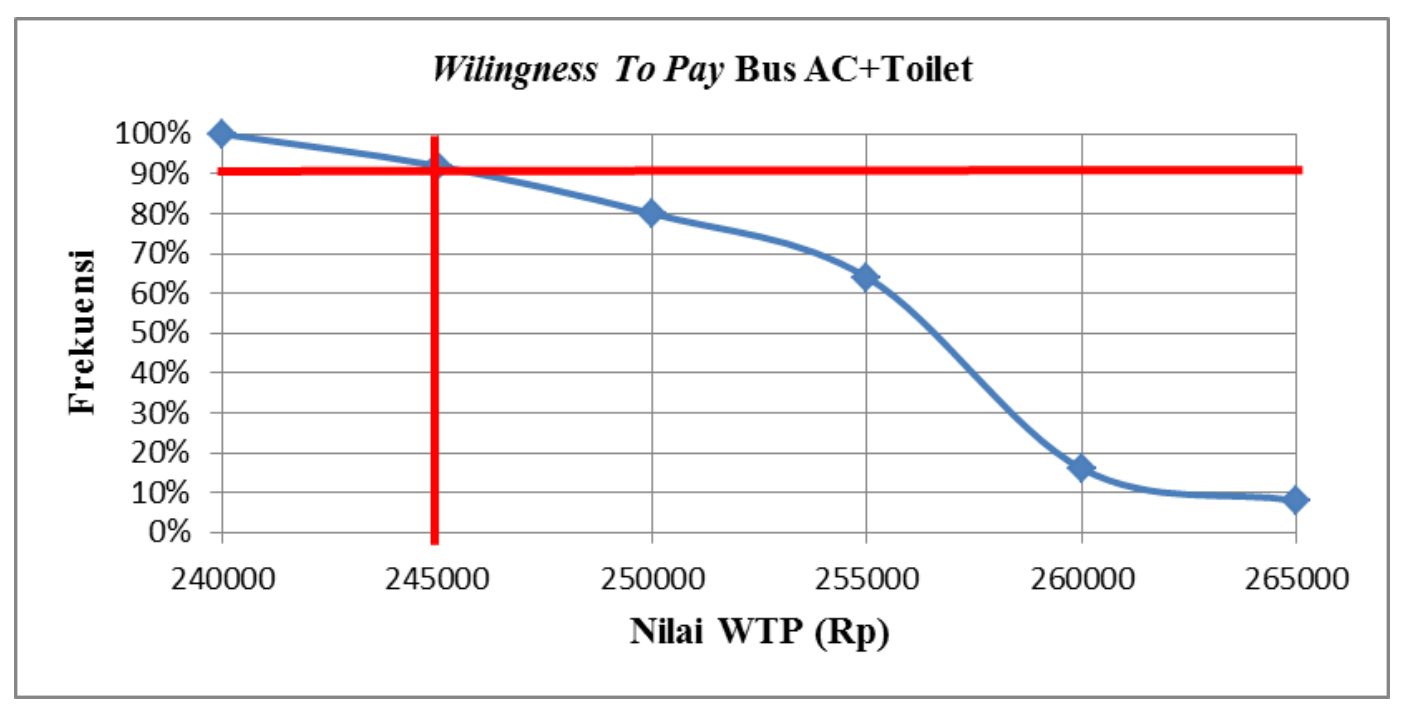

Gambar 3. Kurva Willingness To Pay Bus AC+Toilet 
Hasil kurva Willingness To Pay bus AC+Toilet dipilih $90 \%$ frekuensi responden dengan nilai WTP sebesar Rp 245.000.

\section{Pembahasan}

Pada perhitungan BOK untuk PO. Pulau Indah Jaya menggunakan perhitu-ngan berdasarkan berdasarkan metode PCI dan hasil wawancara. Alasan ditetap-kan perhitungan tersebut karena jumlah nilai hasil perhitungan pada biaya pemeliharaan dan biaya suku cadang menghasilkan nilai biaya pengeluaran lebih besar ketimbang pengeluaran dari PO. Pulau Indah Jaya jika menggunakan metode PCI oleh sebab itu digunakan data hasil wawancara. Berdasarkan perhitungan WTP (Willingness To Pay) yang telah dilakukan, dengan harga tarif bus yang berlaku saat ini untuk bus Non AC sebesar Rp 175.000 dan bus AC+Toilet sebesar Rp 235.000 didapatkan nilai WTP bus untuk tipe Non AC dan AC+Toilet. Berdasarkan hasil kurva Willingness To Pay bus Non AC dipilih $80 \%$ frekuensi responden dengan nilai WTP sebesar Rp 185.000 dan hasil kurva Willingness To Pay bus AC+Toilet dipilih $90 \%$ frekuensi responden dengan nilai WTP sebesar Rp 245.000. Nilai WTP yang dipakai adalah hasil dari kurva frekuensi kumulatif WTP. Hasil analisis dari perhitungan WTP (Willingness To Pay) menunjukkan respon penumpang terhadap penambahan biaya tarif bus AKAP dengan ditambah pelayanan dan fasilitas cukup besar keinginannya mendapatkan peningkatan dari pelayanan dan fasilitas yang sudah tersedia saat ini.

\section{PENUTUP}

\section{Kesimpulan}

Hasil dari penelitian ini berdasarkan analisis dan pembahasan adalah:

1. Komponen biaya yang ada pada Biaya Operasional Kendaraan (BOK) yaitu: Biaya Tetap, Biaya Tidak Tetap dan Biaya Overhead.

2. Besar nilai BOK bus AKAP Non AC sebesar Rp 8.137.912.279/tahun dan bus AKAP AC+Toilet sebesar Rp 8.712.239.580/tahun.

3. Nilai tarif untuk bus AKAP Non AC sebesar Rp 168.194 /penumpang dan untuk bus AKAP AC+Toilet sebesar Rp 229.173 /penumpang. Besar nilai tarif dari BOK lebih kecil dari tarif yang berlaku saat ini.

4. Besar nilai WTP bus AKAP Non AC hasil kurva kumulatif WTP adalah sebesar Rp 185.000 dan bus AKAP AC+Toilet sebesar Rp 245.000.

5. Penambahan pelayanan dan fasilitas bus AKAP yang paling banyak diinginkan oleh penumpang adalah:

a. Kenyamanan, penumpang menginginkan kenyamanan lebih dari fasilitas yang sudah ada saat ini pada bus AKAP.

b. Keselamatan, penumpang ingin mendapatkan rasa aman dan terlindungi pada saat menaiki bus AKAP.

c. Keteraturan, penumpang ingin kepastian jadwal bus datang dan pergi serta minim atau tidak terjadi keterlambatan.

\section{Saran-saran}

Beberapa pertimbangan dan perbaikan yang dapat dilakukan yaitu: perlu peningkatan pelayanan dan fasilitas pada hal kenyamanan, keselamatan dan keteraturan serta diilakukan pendetailan perhitungan BOK untuk memperoleh hasil yang lebih spesifik. 


\section{DAFTAR PUSTAKA}

Bina Marga Dep. PU. 1995. Perhitungan Biaya Operasional Kendaraan (BOK). Pd T-15-2005-B Jakarta.

C. Jotin Khisty \& B. Kent Lall. 2003. Dasar-dasar Rekayasa Transportasi jilid 1 edisi ketiga. Penerbit Erlangga, Jakarta.

Isgianto, A. 2009. Teknik Pengambilan Sampel. Jogjakarta : Mitra Cendikian Press

Lembaga Afiliasi Penelitian dan Industri (LAPI) ITB. 1996. Laporan Akhir Studi Perhitungan Biaya Operasi Kendaraan PT. Jasa Marga. ITB : Bandung.

Morlok. Edward K. 1978, Pengantar Teknik dan Perencanaan Transportasi, Penerbit Erlangga, Jakarta.

Nazir. 2003. Metode Penelitian Edisi 5. Jakarta, Penerbit : Ghahlia Jakarta.

Nugroho, Handy \& Purwaningsih, Ratna. 2015. Analisis Tarif Berdasarkan Biaya Operasional Kendaraan (BOK) dan Willingness To Pay (WTP) Pada Bus AKAP Kelas Executive. Studi Kasus : Bus Rosalia Indah Executive Jurusan Solo-Jabodetabek. Skripsi Program Studi Teknik Industri Fakultas Teknik Universitas Diponegoro.

Nuryati, Sri. 2012. Analisis Biaya Pengguna Jalan Di Wilayah JABODETABEK. Skripsi Jurusan Teknik Sipil Fakultas Teknik Sipil Universitas Muhammadiyah Tangerang.

Peraturan Presiden No. 54 Tahun 2010, Tentang Pengadaan Barang Dan Jasa, Jakarta.

Pudjianto, Bambang. 2002. Bahan Kuliah Sistem Angkutan Umum dan Barang. Semarang : UNDIP.

Ruslan, Norman. 2004. Optimalisasi Umur Guna Kendaraan Angkutan Umum. Vol 5, No 2: INFOTEKNIK

Tamin, O. Z., dkk. 1999. Studi Evaluasi Tarif Angkutan Umum dan Analisis Ability To Pay (ATP) dan Willingness To Pay (WTP) di DKI Jakarta. Jurnal Transportasi. Forum Studi Transportasi antar Perguruan Tinggi (FSTPT). Vol 1, No 2, hal 121-135, ISSN: 1411-2442. Bandung.

Warpani, Suwardjoko. 1990. Merencanakan Sistem Perangkutan. Bandung : Penerbit ITB.

Warpani, Suwardjoko. 2002. Pengelolaan Lalu Lintas dan Angkutan Jalan. Bandung : Penerbit ITB.

Yuniarti, Taty. 2009. Analisis Tarif Angkutan Umum Berdasarkan Biaya Operasional Kendaraan, Analisis Ability To Pay dan Willingness To Pay. Studi Kasus PO. ATMO Trayek Palur-Kartasura di Surakarta. Skripsi Program Studi Teknik Sipil Fakultas Teknik Universitas Sebelas Maret.

Zulfikar. 2015. Analisis Ability To Pay dan Willingness To Pay Penumpang Angkutan Umum Minibus L 300. Studi Kasus :Rute Meulaboh di Banda Aceh. Skripsi Program Studi Teknik Sipil Fakultas Teknik Universitas Teuku Umar Alue Peunyareng Meulaboh. 